\title{
TEKNIK PENABURAN BENIH MERBAU (Intsia bijuga) SECARA LANGSUNG DI HUTAN PENELITIAN PARUNGPANJANG, BOGOR
}

\author{
Direct Seeding Technique of Merbau (Intsia bijuga) at Parungpanjang \\ Research Forest, Bogor \\ Nurhasybi dan/and Dede J. Sudrajat \\ Balai Penelitian Teknologi Perbenihan Bogor \\ Jl. Pakuan, Ciheuleut, P.O.Box 16001 Bogor, Telp./Fax : 0251 - 8327768 \\ Naskah masuk : 16 Juni 2008; Naskah diterima : 8 Juni 2009
}

\begin{abstract}
It is estimated that degraded forest areas in Indonesia have reached 59.7 million ha with the alarming deforestation rate more or less than 3 million halyear. Constraint in nature regeneration (i.e. forest and land rehabilitation) and limitation in budget have enforced to adopt other methods as alternative for those rehabilitations. Among alternatives is the so-called direct seeding to grow pioneer species thereby enhancing favorable condition for local species. This research used merbau (Intsia bijuga) seeds with factorial design. The seed was sowed on under tree stands and in open area in the way of: (1) the untreated seeds were sown on the site soil surface, which had been left uncleared, (2) the untreated seeds were sown on the site soil surface, which had been holed with $2-3 \mathrm{~cm}$ depth, cleared and loosened, (3) the untreated seed were sown on the site-soil surface which had been cleared and loosened, (4) the seeds were scarified and then soaked in water for 30 minutes, sown on the site soil surface afterwards, which had been cleared and loosened, and (5) the seeds were scarified and then soaked in water for 30 minutes, afterwards sown on the site soil surface, which had been holed with $2-3 \mathrm{~cm}$ depth, cleared and loosened. The observed parameters were seedling percentage and diameter. Assessment on the acquired parameter was assisted by a Completely Randomized Design with two factors. The results revealed that the direct seeding was better conducted under tree stands than in open area, because the former offered higher relative humidity $(R H)$ than the later with shading intensity vary from $50 \%$ to $65 \%$. Meanwhile, greatest seedling diameter was achieved by the implementation of seed-scarifying treatment to overcome seedcoat dormancy and seed-soaking in water for 30 minutes, followed with seed sowing on the site surface and on the site surface which had been holed with $2-3 \mathrm{~cm}$ depth which had been cleared and loosened as well as with seed sowing. Implementation of direct seeding of merbau as such on site or circle shapes can been done in secondary forest or shrubs, since in this way the seed can grow well.
\end{abstract}

Key words : direct seeding, forest and land rehabilitation, merbau (Intsia bijuga) seeds

\begin{abstract}
ABSTRAK
Luas kerusakan hutan di Indonesia mencapai 59,7 juta hektar dengan laju kerusakan kurang lebih 3 juta hektar per tahun. Adanya keterbatasan regenerasi alami dan kendala biaya yang besar untuk penanaman membutuhkan metode lain yang dapat dijadikan alternatif rehabilitasi hutan dan lahan, yaitu dengan penaburan benih secara langsung (direct seeding) untuk menumbuhkan jenis-jenis pionir yang akan menciptakan kondisi untuk tumbuhnya jenis-jenis lokal. Penelitian ini menggunakan jenis merbau (Intsia bijuga) dengan rancangan faktorial. Benih ditabur di bawah tegakan dan di tempat terbuka, dengan cara : (1) benih tanpa perlakuan ditabur di atas permukaan tapak yang tidak dibersihkan, (2) benih tanpa perlakuan kemudian ditabur dengan cara ditugal sedalam $2-3 \mathrm{~cm}$ pada tapak yang sudah dibersihkan dan digemburkan, (3) benih tanpa perlakuan ditabur di atas permukaan tapak yang sudah dibersihkan dan digemburkan, (4) benih dikikir dan direndam air selama 30 menit kemudian ditabur di atas permukaan pada tapak yang sudah dibersihkan dan digemburkan, dan (5) benih dikikir dan direndam air selama 30 menit kemudian ditabur dengan cara ditugal sedalam $2-3 \mathrm{~cm}$ pada tapak yang sudah
\end{abstract}


dibersihkan dan digemburkan. Parameter yang diukur meliputi daya tumbuh benih dalam bentuk kecambah dan pertumbuhan semai. Hasil penelitian menunjukkan penaburan benih merbau (I. bijuga) lebih baik dilakukan di bawah tegakan dengan intensitas naungan $50-65 \%$. Pertumbuhan diameter semai merbau menunjukkan nilai terbaik pada perlakuan benih dikikir untuk memudahkan benih tumbuh karena kulit benihnya tebal dan direndam air selama 30 menit kemudian ditabur di atas permukaan atau ditabur dengan cara ditugal sedalam 2 - $3 \mathrm{~cm}$ pada tapak yang sudah dibersihkan dan digemburkan. Penerapan penaburan benih secara langsung untuk jenis merbau dapat dilakukan pada hutan sekunder atau semak belukar berupa cemplongan atau jalur, karena benih masih mendapat cukup kelembaban untuk tumbuh.

\section{Kata kunci : merbau (Intsia bijuga), penaburan benih secara langsung, rehabilitasi hutan dan lahan}

\section{PENDAHULUAN}

Laju kerusakan hutan di Indonesia mencapai 3 juta hektar per tahun dengan total hutan yang mengalami kerusakan mencapai 59,7 juta hektar, sedangkan kegiatan rehabilitasi hutan dan lahan melalui GERHAN sampai tahun 2009 diperkirakan hanya mencakup luasan 3 juta hektar (Direktorat Perbenihan Tanaman Hutan, 2006). Adanya keterbatasan regenerasi alami dan buatan untuk mengembalikan fungsi dan keberadaan hutan, membutuhkan terobosan lain yang dapat dijadikan metode alternatif (Duryea, 2000). Regenerasi alami mengalami kesulitan karena pada lahan yang kritis sulit untuk ditemukan pohon yang mampu menghasilkan benih berkualitas, sedangkan penanaman memerlukan waktu dan biaya yang besar. Selain itu, aksesibilitas yang rendah pada sebagian besar lahan kritis membuat kondisi tersebut membutuhkan metode yang praktis dan murah. Beberapa pertimbangan di atas menunjukkan perlunya alternatif metode rehabilitasi hutan dan lahan yang salah satunya dapat ditempuh dengan teknik penaburan benih secara langsung atau direct seeding (Ezell, 2004).

Direct seeding merupakan metode yang telah dikenal lama dan dalam prakteknya juga tidak terlepas dari kekurangan yang berhubungan dengan persyaratan kondisi tempat tumbuh. Namun pada saat kawasan lahan kritis luas dan terbatasnya anggaran pemerintah, metode ini dapat dijadikan alternatif, mengingat beberapa kondisi yang diperlukan dalam penerapannya di Indonesia secara alami telah terpenuhi.

Salah satu jenis yang cukup potensial untuk direct seeding adalah merbau (Intsia bijuga). Jenis ini mempunyai kulit benih yang keras sehingga dapat lebih lama bertahan di lapangan. Penelitian ini bertujuan untuk mengetahui kondisi lahan dan perlakuan benih yang optimum untuk direct seeding merbau di lapangan.

\section{BAHAN DAN METODE}

\section{A. Waktu dan Lokasi Penelitian}

Benih merbau dikumpulkan pada bulan Mei - Juli 2007 di Carita, Banten. Pengujian mutu benih dilaksanakan di Laboratorium Balai Penelitian Teknologi Perbenihan (BPTP) Bogor, sedangkan penelitian lapangan dilaksanakan di Hutan Penelitian Parungpanjang, Bogor. Lokasi terletak pada ketinggian 51,7 m dpl dengan jenis tanah Podsolik Haplik yang memiliki tingkat kesuburan rendah sampai sangat rendah dengan reaksi tanah masam $(\mathrm{pH} 4,8)$. Curah hujan rata-rata $2000-2500 \mathrm{~mm} /$ tahun. Penaburan dilakukan pada bulan Oktober 2007 dan evaluasi pertumbuhannya dilakukan hingga bulan Januari 2008.

\section{B. Rancangan Penelitian}

Rancangan percobaan yang digunakan adalah rancangan acak lengkap faktorial dengan dua faktor, yaitu cara penaburan benih (A) dan tapak penelitian (B), sebagaimana pada Tabel 1. Penaburan benih dilakukan dalam bentuk jalur dengan jumlah benih 100 butir/jalur yang merepresentasikan suatu perlakuan. Setiap jalur terdiri dari 10 plot kecil dengan berukuran 1 x $1 \mathrm{~m}$ yang ditanami 10 butir benih tiap plot. Jarak antar plot dalam satu jalur adalah $3 \mathrm{~m}$ dan jarak antar jalur juga $3 \mathrm{~m}$. Parameter yang 
diukur meliputi daya tumbuh semai, tinggi dan diameter semai pada umur 2 dan 3 bulan.

Tabel(Table) 1. Perlakuan penaburan benih secara langsung jenis merbau (Direct seeding treatment of merbau seeds)

\begin{tabular}{|c|c|c|}
\hline \multirow{2}{*}{$\begin{array}{c}\text { Perlakuan dan cara penaburan } \\
\text { (Sowing treatment and techniques) }\end{array}$} & $\mathrm{B}_{1}$ & $\mathrm{~B}_{2}$ \\
\cline { 2 - 3 } & $\mathrm{A}_{1} \mathrm{~B} 1$ & $\mathrm{~A}_{1} \mathrm{~B}_{2}$ \\
\hline $\mathrm{A}_{1}$ & $\mathrm{~A}_{2} \mathrm{~B}_{1}$ & $\mathrm{~A}_{2} \mathrm{~B}_{2}$ \\
\hline $\mathrm{A}_{2}$ & $\mathrm{~A}_{3} \mathrm{~B}_{1}$ & $\mathrm{~A}_{3} \mathrm{~B}_{2}$ \\
\hline $\mathrm{A}_{3}$ & $\mathrm{~A}_{4} \mathrm{~B}_{1}$ & $\mathrm{~A}_{4} \mathrm{~B}_{2}$ \\
\hline $\mathrm{A}_{4}$ & $\mathrm{~A}_{5} \mathrm{~B}_{1}$ & $\mathrm{~A}_{5} \mathrm{~B}_{2}$ \\
\hline $\mathrm{A}_{5}$ & & \\
\hline
\end{tabular}

Keterangan (Notes):

$\mathrm{A} 1=$ Benih tanpa perlakuan ditabur di atas permukaan tapak yang tidak dibersihkan (The untreated seeds were sown on the site soil surface, which had been left uncleared)

A2 $=$ Benih tanpa perlakuan kemudian ditabur dengan cara ditugal sedalam $2-3 \mathrm{~cm}$ pada tapak yang sudah dibersihkan dan digemburkan (The untreated seeds were sown on the site-soil surface, which had been holed with $2-3 \mathrm{~cm}$ depth, cleared and loosened)

A3 = Benih tanpa perlakuan ditabur di atas permukaan tapak yang sudah dibersihkan dan digemburkan (The untreated seed were sown on the site-soil surface which had been cleared and loosened)

A4 = Benih dikikir dan direndam air selama 30 menit kemudian ditabur diatas permukaan pada tapak yang sudah dibersihkan dan digemburkan (The seeds were scarified and then soaked in water for 30 minutes, afterwards sown on the site soil surface, which had been cleared and loosened)

A5 $=$ Benih dikikir dan direndam air selama 30 menit kemudian ditabur dengan cara ditugal sedalam $2-3 \mathrm{~cm}$ pada tapak yang sudah dibersihkan dan digemburkan (The seeds were scarified and then soaked in water for 30 minutes, afterwards sown on the site soil surface, which had been holed with $2-3 \mathrm{~cm}$ depth, cleared and loosened)

$\mathrm{B} 1=$ Di bawah tegakan, jarak antar pohon penaung $6 \mathrm{~m}$ (Under tree stand, distance among shelter trees $6 \mathrm{~m}$ )

B2 = Di tempat terbuka (Open area)

Data hasil pengukuran dianalisis dengan anova, apabila hasil sidik ragam terdapat pengaruh nyata dari perlakuan atau interaksinya, maka dilanjutkan dengan uji Duncan.

\section{HASIL DAN PEMBAHASAN}

Hasil sidik ragam menunjukkan bahwa persentase tumbuh semai dipengaruhi oleh interaksi tapak dan perlakuan baik setelah penaburan 2 bulan maupun 3 bulan (Lampiran 1). Persentase tumbuh terbaik hingga umur 3 bulan ditunjukkan oleh perlakuan $\mathrm{A}_{5} \mathrm{~B}_{1}$ dengan persen hidup sebesar 57,5\% (Tabel 2). Namun, jika dikaitkan dengan kegiatan rehabilitasi lahan yang sebagian besar merupakan areal terbuka maka perlakuan $\mathrm{A}_{5} \mathrm{~B}_{2}$ dapat menjadi pilihan dengan persentase hidup $16 \%$ pada umur 3 bulan. 
Tabel(Table) 2. Uji lanjut Duncan interaksi pengaruh tempat tumbuh dan perlakuan terhadap daya tumbuh benih merbau (Duncan's multiple range test on the effect of site and treatment on merbau's seedling's survival percentage)

\begin{tabular}{|c|c|c|c|}
\hline \multirow{2}{*}{ No. } & Interaksi & \multicolumn{3}{|c|}{ Daya Tumbuh (Survival Percentage) (\%) } \\
\cline { 3 - 4 } & (Interaction) & 2 bulan & 3 bulan \\
\hline 1. & A1B1 & $5,25 \quad \mathrm{~d}$ & $4,75 \mathrm{~cd}$ \\
\hline 2. & A2B1 & $10,00 \quad \mathrm{c}$ & $10,25 \mathrm{bc}$ \\
\hline 3. & A3B1 & $13,75 \quad \mathrm{c}$ & $13,75 \mathrm{bc}$ \\
\hline 4. & A4B1 & $20,50 \mathrm{~b}$ & $20,75 \mathrm{~b}$ \\
\hline 5. & A5B1 & $57,50 \mathrm{a}$ & $57,50 \mathrm{a}$ \\
\hline 6. & A1B2 & $0,50 \mathrm{e}$ & $0,25 \mathrm{~d}$ \\
\hline 7. & A2B2 & $3,25 \mathrm{de}$ & $1,75 \mathrm{~d}$ \\
\hline 8. & A3B2 & $1,75 \mathrm{e}$ & $1,00 \mathrm{~d}$ \\
\hline 9. & A4B2 & $3,25 \mathrm{de}$ & $8,50 \mathrm{c}$ \\
\hline 10. & A5B2 & $21,75 \mathrm{~b}$ & $16,00 \mathrm{~b}$ \\
\hline
\end{tabular}

Keterangan(Note): Angka pada kolom yang diikuti oleh huruf sama tidak berbeda nyata pada tingkat kepercayaan $99 \%$ (Figures in the column followed by the same letters are not significantly different at $99 \%$ level $a>b$ ).

Secara umum persentase hidup semai di bawah tegakan lebih stabil dibandingkan dengan persentase hidup di tempat terbuka. Pada tempat terbuka, persentase hidup terjadi penurunan, seperti pada perlakuan $\mathrm{A}_{5} \mathrm{~B}_{2}$ dari $21 \%$ pada umur 2 bulan menjadi $16 \%$ pada umur 3 bulan. Pada umur 2 bulan diduga semai berada pada kondisi sensitif yang ditandai dengan mulai munculnya tunas dan bagian pertumbuhan linier. Kondisi tersebut menurut Donald (1984), respon terhadap kondisi ini tergantung pada species dan lingkungan.

Pada penelitian ini, suhu dan kelembaban yang cukup fluktuatif terjadi pada tempat terbuka (Gambar 1). Suhu yang lebih tinggi $\left(24-35^{\circ} \mathrm{C}\right)$ dan kelembaban yang rendah $(42-80 \%)$ menyebabkan kondisi tanah lebih kering yang menyebabkan pertumbuhan akar dan tunas menjadi kerdil dan semai menjadi stress dan lama-kelamaan akan mati. Hasil serupa dilaporkan oleh Tucker dan Emmingham (1977) dan Tucker et al. (1987), panas matahari menyebabkan banyak kematian pada bibit Tsuga canadensis, T. heterophylla, dan Abies amabilis. Menurut Asada (1992) kematian ini disebabkan oleh energi fotosintesis yang berlebihan sehingga merusak klorofil yang menyebabkan absisi dan kematian daun yang selanjutnya semai tersebut mati.
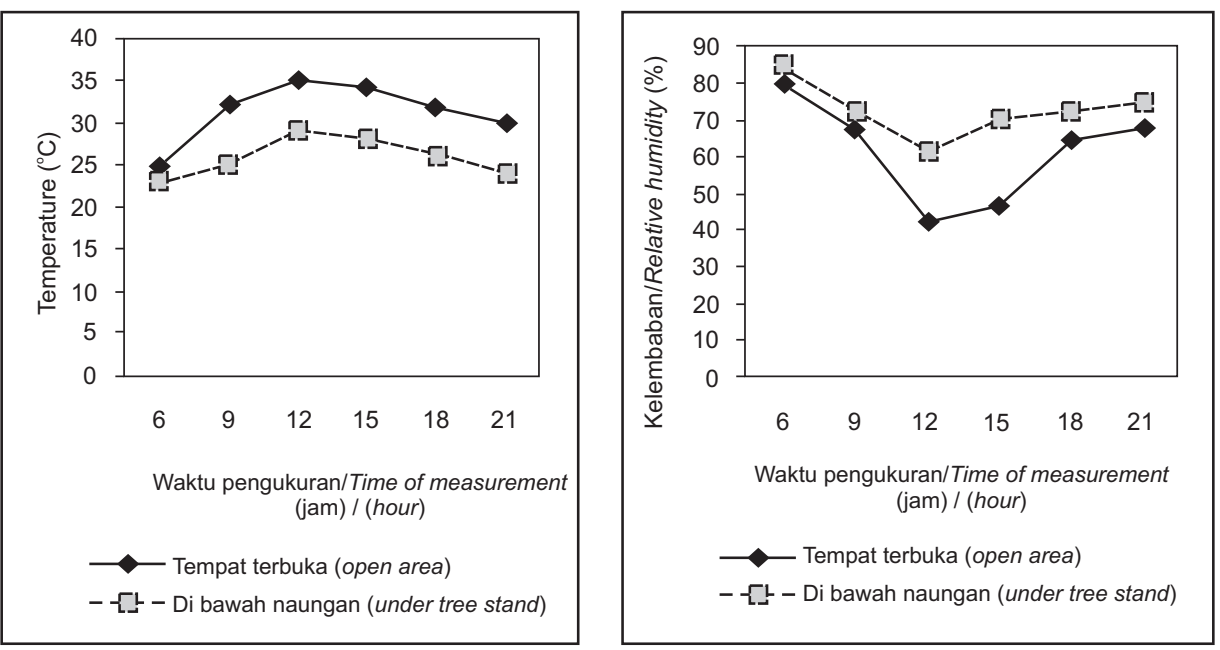

Gambar(Figure) 1. Fluktuasi suhu dan kelembaban di bawah tegakan dan areal terbuka (Fluctuation of temperature and relative humidity under the tree stand and open area) 
Selain kondisi tersebut, benih yang digunakan dan perlakuan benih yang tepat juga sangat mempengaruhi keberhasilan direct seeding. Pada penelitian ini, hasil pengujian benih memiliki daya berkecambah yang cukup baik (85-95\%). Menurut Williston dan Balmer (1983), untuk mendapatkan hasil yang baik, benih yang digunakan sebaiknya benih yang memiliki daya berkecambah lebih dari $85 \%$. Perlakuan pendahuluan pada jenis benih yang memiliki dormansi sangat diperlukan untuk meningkatkan dan mempercepat proses perkecambahan (Schmidt, 2000). Seperti pada benih Acacia mangium yang ditabur secara langsung dan dipatahkan dormansinya dengan pembakaran terkontrol di lahan yang ditumbuhi alang-alang memberikan hasil yang cukup menjanjikan dengan persentase tumbuh sebesar 10 $\%$ (Mile, 1998).

Benih merbau memiliki dormansi kulit benih sehingga memerlukan perlakuan pendahuluan sebelum ditaburkan dan memerlukan kelembaban yang cukup untuk tumbuh sehingga benih yang ditabur di bawah tegakan jumlahnya lebih banyak dibandingkan dengan yang tumbuh di tempat terbuka. Kondisi ini kemungkinan karena secara mekanis proses membukanya kulit benih lebih mudah di bawah tegakan. Di tempat terbuka masih ditemukan benih segar yang masih belum berkecambah.

Pengolahan lahan dalam penelitian ini memberikan perbedaan yang nyata terhadap keberhasilan direct seeding. Lahan yang dibersihkan dan digemburkan dengan penaburan benih ditugal memberikan hasil terbaik. Penaburan benih di atas permukaan tanah memang cukup efisien dan menghemat tenaga tetapi menghadapi resiko benih hanyut oleh air hujan atau diganggu oleh binatang. Menurut Johnson (1980), kedalaman benih dibenamkan dalam tanah akan berpengaruh terhadap daya berkecambah benih. Benih Quercus memberikan perkecambahan terbaik pada benih yang ditanam pada kedalaman 2 inchi. Benih yang dibenamkan terlalu dangkal kemungkinan akan lebih mudah diserang serangga atau binatang lainnya (Johnson dan Krinard, 1985).

Waktu penerapan direct seeding di lapangan perlu menjadi perhatian, seperti percobaan di Stoneville, Mississippi, Amerika Serikat yang menunjukkan bahwa benih Quercus yang ditabur pada bulan yang berbeda menunjukkan persentase yang berbeda yang ditunjukkan oleh masing-masing pertumbuhan pada bulan Mei (67\%), Juni (78\%), Juni (78\%) dan Agustus (59\%) (Johnson dan Krinard, 1985). Pada penelitian ini, penaburan dilakukan pada awal musim hujan (Oktober 2007). Kondisi iklim mikro saat itu cukup mendukung proses perkecambahan, namun adanya kondisi iklim yang tidak menentu menyebabkan curah hujan kurang menentu. Pada bulan Desember curah hujan berkurang dan sempat tidak turun hujan selama 2 minggu sehingga menyebabkan banyaknya kematian semai setelah umur 2 bulan terutama di areal terbuka.

Pertumbuhan tinggi semai dipengaruhi oleh tapak hingga umur 2 bulan, tetapi setelah 3 bulan, tapak tersebut tidak menunjukkan pengaruh yang nyata. Untuk diameter semai, interaksi tapak dengan perlakuan berpengaruh nyata hingga 2 bulan, tetapi setelah 3 bulan tidak menunjukkan pengaruh nyata (Lampiran 1).

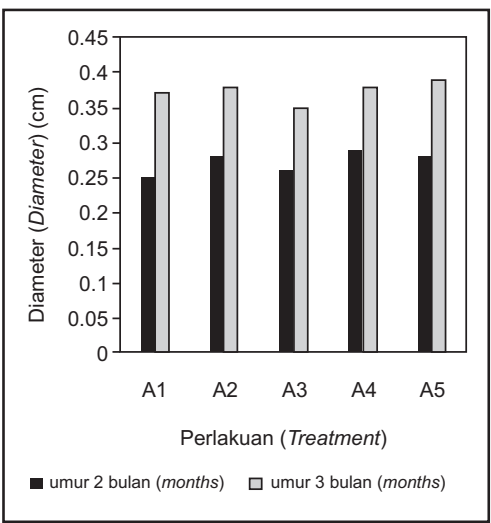

(a)

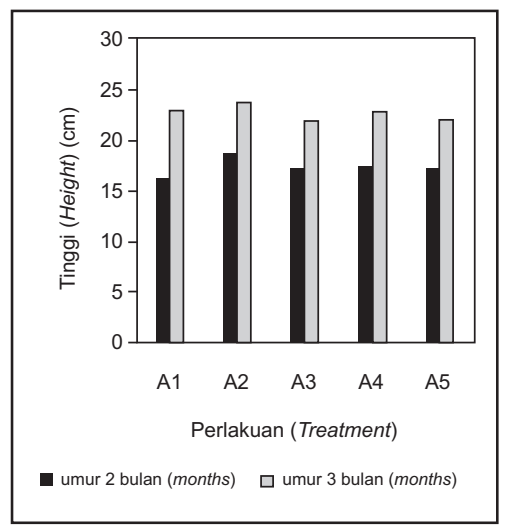

(b)

Gambar(Figure) 2. Pertumbuhan diameter (a) dan tinggi (b) bibit merbau pada berbagai perlakuan (Diameter (a) and height (b) growth of merbau seedling on various treatments). Keterangan (Note): Angka yang diikuti oleh huruf yang sama pada label data diagram batang tidak berbeda nyata pada tingkat kepercayaan 99\% (Figure followed by the same letters on the data labels on the chart are not significantly different at $99 \%$ confidencelevel) 
Berdasarkan Gambar 2, benih tanpa perlakuan kemudian ditabur dengan cara ditugal sedalam 2 -3 cm pada tapak yang sudah dibersihkan dan digemburkan (A2) menghasilkan pertumbuhan lebih baik dibandingkan perlakuan lainnya hingga umur 2 bulan, namun pada umur 3 bulan perbedaan tersebut relatif kecil dan antar perlakuan yang diuji tidak memberikan perbedaan nyata. Hal ini disebabkan oleh kematian semai yang tumbuh belakangan yang diduga mempunyai vigor rendah sehingga tinggi dan diameter semai di antara perlakuan tersebut pada umur 3 bulan relatif lebih seragam. Menurut Seiwa (1998), benih yang berkecambah lebih cepat mempunyai daya adaptasi yang lebih tinggi untuk tumbuh di lapangan.

Pertumbuhan tinggi dan diameter mengindikasikan bahwa benih yang lebih cepat tumbuh memiliki vigor yang lebih baik dan sebagian besar akan bertahan hidup hingga mencapai tanaman dewasa. Pertumbuhan selanjutnya lebih ditentukan oleh kondisi tanah (ketersediaan hara, air dan lainnya) sehingga sehingga pada umur 3 bulan semai yang tersisa merupakan semai yang berasal dari benih yang lebih cepat berkecambah yang mampu menjadi semai permanen (target seedling), yaitu kondisi semai sudah stabil beradaptasi, mampu tumbuh dan berkembang dengan baik. Seluruh karakter semai bekerja secara terpadu untuk menghasilkan suatu hasil sebagai respon yang diinginkan oleh kondisi tempat tumbuh (Hawkins, 1996).

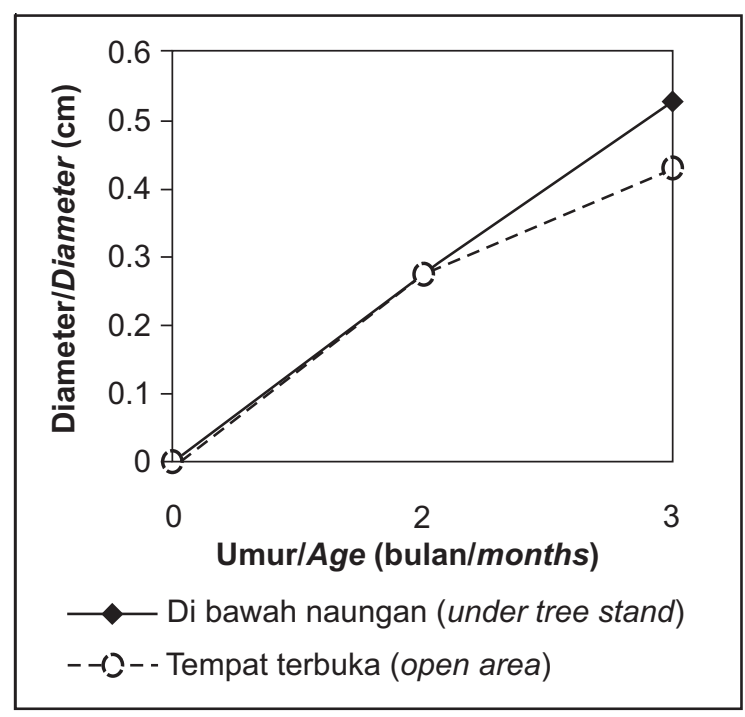

a

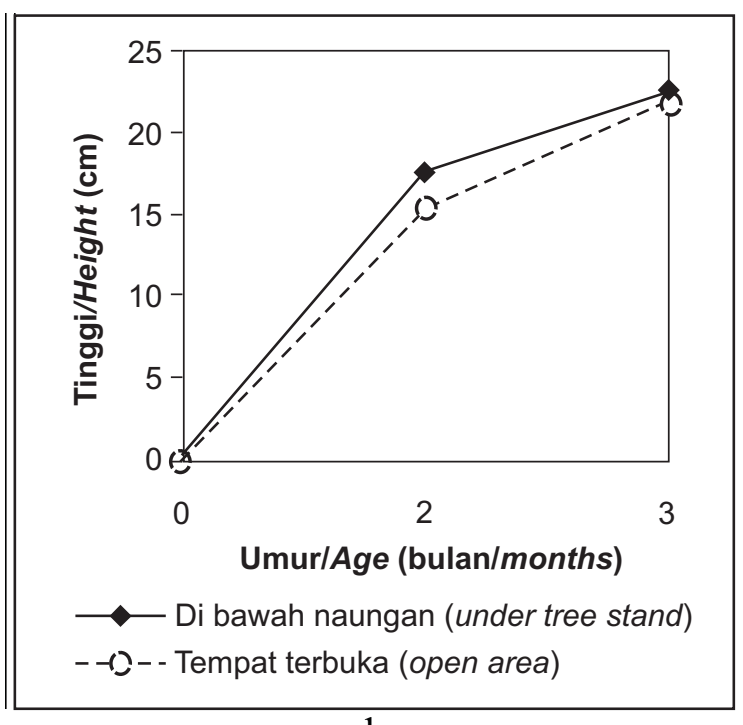

b

Gambar(Figure) 3. Pertumbuhan diameter dan tinggi bibit merbau pada tapak berbeda (Diameter and height growth of merbau seedling at different site). Catatan (Note): Angka yang diikuti oleh huruf yang sama tidak berbeda nyata pada tingkat kepercayaan $99 \%$ (Figure followed by the same letters are not significantly different at $99 \%$ confident level)

Pertumbuhan tinggi semai merbau di bawah tegakan lebih baik dan berbeda nyata dibandingkan dengan di tempat terbuka pada umur 3 bulan, sedangkan untuk diameternya hanya berbeda nyata hingga umur 2 bulan (Gambar 3). Kemungkinan pada lahan terbuka kondisi fisik dan kimia tanah lebih jelek sebagai akibat erosi, sebagai contoh pada tanah terbuka di Parungpanjang $\mathrm{N}$ total hanya $0,10 \%$ (Pusat Penelitian Tanah dan Agroklimat, 1991), sedangkan pada lahan di bawah tegakan berkisar antara 0,160,30\% (Mulyani, 2008).

Selain itu, faktor iklim mikro juga berpengaruh. Pada lahan terbuka suhu lingkungan relatif lebih tinggi, kelembaban rendah, dan radiasi matahari tinggi. Menurut Gates (1968), kondisi tersebut menyebabkan stomata menutup pada saat radiasi matahari tinggi. Proses tersebut juga menyebabkan ukuran daun mengecil untuk mengurangi transpirasi. Hal ini menyebabkan pertumbuhannya menjadi lebih rendah. Sementara, kondisi suhu dan kelembaban di bawah naungan relatif lebih stabil dan lebih mendukung pertumbuhan awal semai merbau membutuhkan naungan sekitar 55-65\% untuk pertumbuhan 
optimalnya. Umumnya, makin tinggi intensitas cahaya mengakibatkan pertumbuhan makin rendah (Nurhasybi et al., 2007).

\section{KESIMPULAN}

1. Penaburan benih merbau (Intsia bijuga) lebih baik dilakukan di bawah tegakan atau tempat yang terlindung, pada intensitas naungan $55-65 \%$.

2. Pertumbuhan diameter semai merbau terbaik pada perlakuan benih dikikir dan direndam air selama 30 menit kemudian ditabur di atas permukaan dan dengan cara ditugal sedalam $2-3 \mathrm{~cm}$ pada tapak yang sudah dibersihkan dan digemburkan.

3. Penerapan penaburan benih secara langsung untuk jenis merbau dapat dilakukan pada hutan sekunder atau semak belukar dalam bentuk jalur atau cemplongan dimana benih masih mendapat cukup kelembaban untuk tumbuh.

\section{DAFTAR PUSTAKA}

Asada, K. 1992. Ascorbate Peroxidase-A Hydrogen Peroxidase-Scavenging Enzyme in Plants. Physiology Plant. 85:235-241.

Direktorat Perbenihan Tanaman Hutan. 2006. Regulasi Pengelolaan Sumber Benih. Direktorat Perbenihan Tanaman Hutan Ditjen RLPS. Proceeding seminar benih untuk rakyat : menggunakan dan memproduksi benih secara mandiri, 4 Desember 2006. Balai Penelitian Teknologi Perbenihan Bogor. Bogor.

Duryea, M.L. 2000. Forest Regeneration Methods: Natural Regeneration, Direct Seeding and Plantation. Florida Cooperative Extention Service, Institute of Food and Agricultural Science. University of Florida.

Ezell, A.W. 2004. Direct Seeding : A Forest Regeneration Alternative. Dept. of Forestry, MSU. Mississippi. USA.

Gates, D.M. 1968. Transpiration and Leaf Temperature. Annual Review Plant Physiology. 19:107-118.

Hawkins, B.J. 1996. Planting Stock Quality Assessment. Yapa, A. C., ed. 1996. Proc. Intl. Symp. Recent Advances inTropical Tree Seed Technol. and Planting tock Production. ASEAN Forest Tree Seed Centre, Muaklek, Saraburi, Thailand.

Johnson R.L. and R.M. Krinard. 1985. Oak regeneration by direct seeding. Alabama's Treasured Forests Vol. IV, No. 3, 1983, p. 12-15. Mississippi.

Johnson, R.L. 1980. New Ideas about Regeneration of Hardwoods. Proc. Hardwood Regeneration Symp. Southeast umber Manuf. Assoc., Forest Park. p 17-19.

Mann, W.F., Jr. 1961. Guidelines for Direct Seeding Loblolly Pine. US. Forest Services. Pp. 188.

Mile, Y. 1998. Country Paper in Acacias for Amenity Planting and Environmental Conservation. Proceeding of COGREDA. Taipei, Taiwan.

Mulyani. 2008. Penampilan Tanaman Pulai, Jabon, dan Kiputih di Hutan Penelitian Parungpanjang, Bogor. Fakultas Matematika dan Ilmu Pengetahuan Alam. Universitas Pakuan. Bogor.

Nurhasybi, D.J. Sudrajat, A.A. Pramono, dan B. Budiman. 2007. Review Status Iptek Perbenihan Tanaman Hutan. Publikasi Khusus Vol. 6. Balai Penelitian Teknologi Perbenihan. Bogor.

Pusat Penelitian Tanah dan Agroklimat. 1991. Pengambilan dan Pengujian Sampel Tanah di Hutan Penelitian Parungpanjang. Kerjasama Pusat Penelitian Tanah dan Agroklimat dan Balai Teknologi Perbenihan. Bogor. 
Schmidt, L. 2002. Pedoman Penanganan Benih Tanaman Hutan Tropis dan Sub Tropis 2000. Terjemahan. Direktorat Jenderal Rehabilitasi Lahan Dan Perhutanan Sosial. Departemen Kehutanan.

Seiwa, K. 1998. Advantages of Early Germination for Growth and Survival of Seedlings of Acer Mono under Different Overstorey Phenologies in Deciduous Broad Leaved Forests. Journal of Ecology. 86.219-228.

Tucker, G.F. dan W.H. Emmingham. 1977. Morphological Changes in Leaves of Residual Western Hemlock after Clear and Shelter Wood Cutting. Forest Science. 23:195-203.

Tucker, GF., T.M. Hinckley, J. Leverenz, dan S. Jiang. 1987. Adjusment of Foliar Morphology in the Acclimation of Understory Pacific Silver Fir Following Clearcutting. Forest Ecology andManagement. 21:249-268.

Williston, H.L. Dan W.E. Balmer. 1983. Direct Seeding of Southern Pines - A Regeneration Alternative. USDAForest Service. Southern Region. Forestry Bulletin R8-FB/M1. 6 p. 
Lampiran (Appendix) 1. Hasil sidik ragam daya tumbuh semai dan pertumbuhan semai merbau (Results analysis of variance on seedling percentage and growth of merbau seedlings)

\begin{tabular}{|c|c|c|c|}
\hline \multirow{2}{*}{$\begin{array}{c}\text { Parameter } \\
\text { (Parameters) }\end{array}$} & \multirow{2}{*}{$\begin{array}{l}\text { Sumber keragaman } \\
\text { (Sources of variation) }\end{array}$} & \multicolumn{2}{|c|}{$\begin{array}{l}\text { F hitung } \\
(F-\text { calc. })\end{array}$} \\
\hline & & $\begin{array}{l}\text { Umur } 2 \text { bulan } \\
(2 \text { months })\end{array}$ & $\begin{array}{l}\text { Umur } 3 \text { bulan } \\
\text { (3 months) }\end{array}$ \\
\hline \multirow{3}{*}{$\begin{array}{l}\text { Persen tumbuh } \\
\text { (Growth percentage) }\end{array}$} & Tapak (site) & $37,605 * *$ & $32,843 * *$ \\
\hline & Perlakuan (treatments) & $28,211 * *$ & $19,822 * *$ \\
\hline & $\begin{array}{l}\text { Tapak x perlakuan } \\
(\text { site } x \text { treatments })\end{array}$ & $4,950 * *$ & $5,654 * *$ \\
\hline \multirow{3}{*}{$\begin{array}{l}\text { Tinggi } \\
\text { (Height) }\end{array}$} & Tapak (site) & $7,690 * *$ & $0,173 \mathrm{~ns}$ \\
\hline & Perlakuan (treatments) & $1,341 \mathrm{~ns}$ & $1,334 \mathrm{~ns}$ \\
\hline & $\begin{array}{l}\text { Tapak x perlakuan } \\
\text { (site } x \text { treatments) }\end{array}$ & $1,084 \mathrm{~ns}$ & $1,616 \mathrm{~ns}$ \\
\hline \multirow{3}{*}{$\begin{array}{l}\text { Diameter } \\
\text { (Diameter) }\end{array}$} & Tapak (site) & $0,247 \mathrm{~ns}$ & $2,077 *$ \\
\hline & Perlakuan (treatments) & $2,934 *$ & $0,586 \mathrm{~ns}$ \\
\hline & $\begin{array}{l}\text { Tapak x perlakuan } \\
\text { (site } x \text { treatments) }\end{array}$ & $2,930 *$ & $0,278 \mathrm{~ns}$ \\
\hline
\end{tabular}

